\title{
Pharmacokinetics of Orbifloxacin in Mehsana Goats after Intravenous and Intramuscular Administration
}

\author{
Ghanshyam D*, Avinash, Divyesh K, Madhavi A, Bhavesh C, Hitesh P and Shailesh M
}

Department of Pharmacology and Toxicology, College of Veterinary Science and Animal Husbandry, Sardarkrushinagar Dantiwada Agricultural University, Sardarkrushinagar-385506, Gujarat, India

\begin{abstract}
Single-dose pharmacokinetics of orbifloxacin $(2.5 \mathrm{mg} / \mathrm{kg}$ bodyweight) were determined in clinically normal female mehsana goats $(n=6)$ following intravenous and intramuscular administration. Orbifloxacin concentrations were determined by high performance liquid chromatography with ultraviolet detection. The concentration-time data were analyzed by non-compartmental kinetic method. Following a single intravenous injection, an elimination half-life $\left(\mathrm{t}_{12 \beta}\right)$ of $8.63 \pm 0.130 \mathrm{~h}$. Steady-state volume of distribution $\left(\mathrm{Vd}_{\mathrm{ss}}\right)$ and total body clearance $\left(\mathrm{Cl}_{\mathrm{B}}\right)$ were $2.99 \pm 0.038$ $\mathrm{L} / \mathrm{kg}$ and $0.187 \pm 0.002 \mathrm{~L} / \mathrm{kg} / \mathrm{h}$, respectively. Following intramuscular administration, the elimination rate constant $(\beta)$, the area under the curve from zero to infinity $\left(\mathrm{AUC}_{0-\infty}\right)$ and the mean absorption time (MAT) were $0.019 \pm 0.001$ $\mathrm{h}^{-1}, 19.66 \pm 0.216 \mu \mathrm{g} \cdot \mathrm{h} / \mathrm{mL}$ and $7.618 \pm 0.549 \mathrm{~h}$, respectively. The peak plasma concentration $\left(\mathrm{C}_{\max }\right)$ of $1.76 \pm 0.010$ $\mu \mathrm{g} / \mathrm{mL}$ was achieved at $1.00 \pm 0.00 \mathrm{~h}$. The mean residence time (MRT) was $21.07 \pm 0.478 \mathrm{~h}$ and the absolute bioavailability were $155.5 \pm 2.487 \%$, respectively. Orbifloxacin could be useful for the treatment of bacterial infections in goats that are sensitive to this drug.
\end{abstract}

Keywords: Orbifloxacin; Pharmacokinetics; Goats; High performance liquid chromatography

\section{Introduction}

Fluoroquinolones developed over the past few years have greater potency, a broader spectrum of activity, greater in vivo efficacy against resistant organisms and possess a better safety profile than other antimicrobial agents. Orbifloxacin is a third generation synthetic fluoroquinolone, an antimicrobial drug developed extensively for use in veterinary medicine $[1,2]$ and it exhibits high bactericidal activity against Gram-positive, Gram-negative and Mycoplasma spp. [3,4] (Table 1). It is commonly used for infections of the skin.

The continuous interest in orbifloxacin has revealed several recent investigations describing their pharmacokinetic studies in pigs [5], cattle calves [2], cats [6], dogs [1,6-8], horses [9,10], goats [11], camels [12], rabbits [13], cattle [14], sheep [15,16] Japanese quail [17], buffalo calves [18] and chickens [19]. These studies have clearly revealed that the pharmacological basis of dosage regimen of orbifloxacin should be determined in the animals in which the drug is to be used clinically. However, no single study is done on the pharmacokinetics of orbifloxacin in goats in India till date. Therefore, we conducted pharmacokinetics of orbifloxacin in goats after intravenous and intramuscular administration.

\section{Materials and Methods}

\section{Experimental animals}

Twelve healthy adult mehsana goats weighing between 25-35 $\mathrm{kg}$ and aged 2-4 years were used in the present study. The animals were procured from Livestock Research Station, Sardarkrushinagar Dantiwada Agricultural University, Sardarkrushinagar, Gujarat, India. Sheep were kept at optimal nutritional conditions and had access to ad libitum water. The animals were kept under observations throughout the study period. The experimental protocol was approved by Institutional Animal Ethics Committee of Sardarkrushinagar Dantiwada Agricultural University, Sardarkrushinagar, Gujarat, India.

\section{Drugs and chemicals}

Orbifloxacin was obtained from Intas pharmaceuticals Ltd.,
Ashram road, Ahmedabad. Water, methanol, potassium dihydrogen orthophosphate, acetonitrile, orthophosphoric acid, disodium hydrogen phosphate and triethylamine of HPLC grade were purchased from S. D. Fine Chem. Ltd, Mumbai.

\section{Experimental design and dosing}

Twelve animals were divided into two groups - Group I and Group II as 6 animals in each group. Single dose intravenous pharmacokinetics study (Group I) and single dose intramuscular pharmacokinetic study (Group II) of orbifloxacin were performed in mehsana goats. Group I animals were administered with orbifloxacin at $2.5 \mathrm{mg} / \mathrm{kg}$ body weight by intravenous route and Group II animals were administered with orbifloxacin at $2.5 \mathrm{mg} / \mathrm{kg}$ body weight by intramuscular route.

\section{Sample collection and preparation of plasma samples}

Five $\mathrm{mL}$ whole blood samples were collected by venipuncture of the jugular vein into $10 \mathrm{~mL}$ heparinized tubes at $0 \mathrm{~min}$ (pre-administration), $5 \mathrm{~min}, 10 \mathrm{~min}, 15 \mathrm{~min}, 0.5,0.75,1,1.5,2,4,6,8,10,12,24,36,48$ and $72 \mathrm{~h}$ after drug administration. The samples were centrifuged at 1600 $\mathrm{rpm}$ for $10 \mathrm{~min}$. The plasma samples were transferred to Cryo-vials (2 $\mathrm{mL}$ capacity) and frozen until HPLC analysis.

\section{Analytical method}

Plasma samples were analyzed by using HPLC system equipped with G1312A pump, UV detector, SIL6B autoinjector and CTO6A

*Corresponding author: Ghanshyam D, Department of Pharmacology and Toxicology, College of Veterinary Science and Animal Husbandry, Sardarkrushinagar Dantiwada Agricultural University, Sardarkrushinagar-385506, Gujarat, India, Tel: +91 9924872823; E-mail: drgvets@gmail.com

Received January 29, 2015; Accepted May 27, 2015; Published May 29, 2015

Citation: Ghanshyam D, Avinash, Divyesh K, Madhavi A, Bhavesh C, et al. (2015) Pharmacokinetics of Orbifloxacin in Mehsana Goats after Intravenous and Intramuscular Administration. J Veterinar Sci Technol 6: 237. doi:10.4172/21577579.1000237

Copyright: ( 2015 Ghanshyam D, et al. This is an open-access article distributed under the terms of the Creative Commons Attribution License, which permits unrestricted use, distribution, and reproduction in any medium, provided the original author and source are credited. 
Citation: Ghanshyam D, Avinash, Divyesh K, Madhavi A, Bhavesh C, et al. (2015) Pharmacokinetics of Orbifloxacin in Mehsana Goats after Intravenous and Intramuscular Administration. J Veterinar Sci Technol 6: 237. doi:10.4172/2157-7579.1000237

\begin{tabular}{|c|c|c|c|}
\hline $\begin{array}{l}\text { Type of } \\
\text { bacteria }\end{array}$ & Activity & Species & References \\
\hline \multirow{5}{*}{ Gram-positive } & \multirow{5}{*}{ in vitro } & Enterobacter faecalis & \multirow{5}{*}[3,4]{} \\
\hline & & Staphylococcus epidermidis & \\
\hline & & Staphylococcus intermedius & \\
\hline & & Staphylococcus aureus & \\
\hline & & Streptococcus pyogenes & \\
\hline \multirow{11}{*}{ Gram-negative } & \multirow{10}{*}{ in vitro } & Escherichia coli & \multirow{9}{*}[4,23]{} \\
\hline & & Salmonella typhimurium & \\
\hline & & Salmonella typhi & \\
\hline & & Salmonella enteritidis & \\
\hline & & Shigella flexneri & \\
\hline & & Klebsiella pneumoniae & \\
\hline & & Enterobacter aerogenes & \\
\hline & & Pseudomonas aerugonosa & \\
\hline & & Proteus mirabilis & \\
\hline & & Pasteurella Spp. & {$[3,4,24,25]$} \\
\hline & $\begin{array}{c}\text { in vitro and ex } \\
\text { vivo }\end{array}$ & Mannheimia hemolytica & [14] \\
\hline Mycoplasma & in vitro & Mycoplasma Spp. & {$[3,4,24,25]$} \\
\hline
\end{tabular}

Table 1: Bactericidal activity of orbifloxacin against different bacteria.

column heater (Agilent 1100 series). Above mentioned system was connected to a computer with Chromeleon Chromatography Data System software.

Plasma proteins were precipitated by adding $1000 \mu \mathrm{L}$ plasma and $1000 \mu \mathrm{L}$ acetonitrile. The mixture was vortexed for $10 \mathrm{~s}$ and centrifuged at $1600 \mathrm{rpm}$ for $10 \mathrm{~min}$. Then, $250 \mu \mathrm{L}$ of supernatant was diluted with $750 \mu \mathrm{L} 0.067 \mathrm{M}$ disodium hydrogen phosphate buffer ( $\mathrm{pH} 7.5$ ). Chromatographic separation was performed by using Chromatopak Peerless Basic $\mathrm{C}_{18}$ column $(250 \times 4.6 \mathrm{~mm}, 5 \mu)$ at $40^{\circ} \mathrm{C}$ with an injection volume of $80 \mu \mathrm{L}$. The mobile phase (43:57) consisted of 430 volumes of buffer and 570 volumes of methanol with a flow rate of $1.5 \mathrm{~mL} / \mathrm{min}$. Buffer was prepared by dissolving $6.8 \mathrm{~g}$ of potassium dihydrogen orthophosphate in $1000 \mathrm{~mL}$ of water and by adding $3 \mathrm{~mL}$ of triethylamine. Then, $\mathrm{pH}$ adjusted to 2.5 with orthophosphoric acid. UV detection was performed at a wavelength of $320 \mathrm{~nm}$.

\section{Validation of analytical methods}

Blank plasma samples were analyzed to check the absence of interference in the elution position of orbifloxacin. Stock solution of $1 \mathrm{mg} / \mathrm{mL}$ orbifloxacin was prepared by dissolving $100 \mathrm{mg}$ powder form of pure drug in $100 \mathrm{~mL}$ of HPLC water. Further dilutions of the stock solution were prepared and spiked into blank plasma to produce calibration curves at different concentrations. Linearity was determined by spiking concentrations of orbifloxacin between 0.0625 $\mu \mathrm{g} / \mathrm{mL}$ and $20 \mu \mathrm{g} / \mathrm{mL}$. The mean correlation coefficient $\left(\mathrm{R}^{2}\right)$ was 0.999 . Standard curves were obtained by orbifloxacin peak area and known concentrations. The retention time of orbifloxacin was $2.43 \mathrm{~min}$ [20]. The detection limit and quantification limit were determined by analysis of spiked samples at low orbifloxacin concentration.

\section{Pharmacokinetic analysis}

Pharmacokinetic parameters were calculated from plasma concentration of orbifloxacin by software PK solution (version 2.0), Summit research services, USA. This program uses non-compartmental model of pharmacokinetic analysis of orbifloxacin.

\section{Results}

No local or system adverse reaction was observed after intravenous or intramuscular injection of orbifloxacin. A semi-logarithmic plot of the mean concentration of orbifloxacin in the plasma following intravenous and intramuscular administration of $2.5 \mathrm{mg} / \mathrm{kg}$ is shown in Figure 1.

A summary of the pharmacokinetic parameters following intravenous and intramuscular administrations is listed in Table 2. In goats, orbifloxacin showed a range of $\mathrm{Vd}_{\mathrm{ss}}$ in between 2.85 to $3.09 \mathrm{~L} / \mathrm{kg}$ and a range of $\mathrm{Cl}_{\mathrm{B}}$ in between 0.181 to $0.194 \mathrm{~L} / \mathrm{kg} / \mathrm{h}$ after intravenous administration. Orbifloxacin was absorbed rapidly after intramuscular administration and the $\mathrm{C}_{\text {max }}$ range was $(1.72$ to $1.79 \mu \mathrm{g} / \mathrm{mL})$ attained after $1.00 \pm 0.00 \mathrm{~h}\left(\mathrm{~T}_{\max }\right)$ after injection (Figure 1). The MAT range was 5.21 to $9.13 \mathrm{~h}$. The systemic bioavailability range after intramuscular administration was 147.3 to $165.2 \%$.

\section{Discussion}

Orbifloxacin was quickly and widely distributed after intravenous administration with a $\mathrm{Vd}_{\mathrm{ss}}$ of $2.99 \pm 0.038 \mathrm{~L} / \mathrm{kg}$, which suggested good

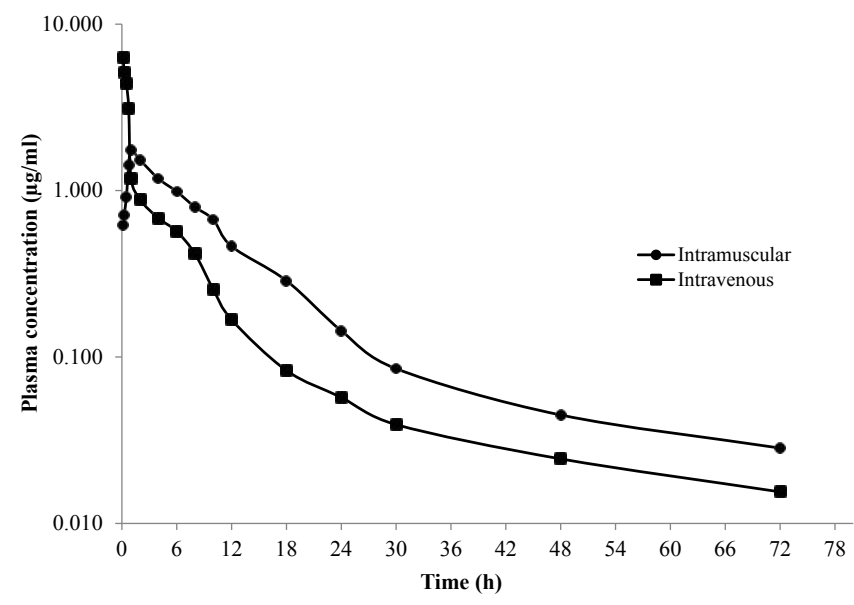

Figure 1: Mean \pm SE plasma concentrations of orbifloxacin in goats after intramuscular and intravenous injection of $2.5 \mathrm{mg} / \mathrm{kg}$ body weight $(\mathrm{n}=6)$.

\begin{tabular}{|c|c|c|c|}
\hline $\begin{array}{c}\text { Pharmacokinetic } \\
\text { parameters }\end{array}$ & Units & Intravenous & Intramuscular \\
\hline$\beta$ & $/ \mathrm{h}$ & $0.020 \pm 0.001$ & $0.019 \pm 0.001$ \\
\hline $\mathrm{t}_{1 / 2 \beta}$ & $\mathrm{h}$ & $8.63 \pm 0.130$ & $17.77 \pm 0.058$ \\
\hline $\mathrm{AUC}_{0-\infty}$ & $\mathrm{V} \eta / \mu \wedge$ & $12.65 \pm 0.208$ & $19.66 \pm 0.216$ \\
\hline $\mathrm{AUMC}$ & $\mu \mathrm{\bullet} \eta^{2} / \mu \wedge$ & $207.6 \pm 0.50$ & $414.4 \pm 12.70$ \\
\hline $\mathrm{Vd}_{\text {area }}$ & $\mathrm{L} / \mathrm{kg}$ & $9.83 \pm 0.172$ & -- \\
\hline $\mathrm{Vd}_{\mathrm{ss}}$ & $\mathrm{L} / \mathrm{kg}$ & $2.99 \pm 0.038$ & -- \\
\hline $\mathrm{Cl}_{\mathrm{B}}$ & $\mathrm{L} / \mathrm{kg} / \mathrm{h}$ & $0.187 \pm 0.002$ & -- \\
\hline $\mathrm{MRT}_{\mathrm{MRT}}$ & $\mathrm{h}$ & $15.57 \pm 0.531$ & $21.07 \pm 0.478$ \\
\hline $\mathrm{MAT}$ & $\mathrm{h}$ & -- & $7.618 \pm 0.549$ \\
\hline $\mathrm{C}_{\max }$ & $\mathrm{V} / \mu \wedge$ & - & $1.76 \pm 0.010$ \\
\hline $\mathrm{T}_{\max }$ & $\mathrm{h}$ & -- & $1.00 \pm 0.00$ \\
\hline $\mathrm{F}$ & $\%$ & -- & $155.5 \pm 2.487$ \\
\hline
\end{tabular}

Key: $\beta$ : Elimination rate constant; $t_{1 / 2 \beta}$ : Elimination half-life; $A_{U C} C_{0-\infty}$ : Area under the curve from zero to infinity; AUMC: Area under first of moment curve; $\mathrm{Vd}_{\text {area }}$ Apparent volume of distribution; $\mathrm{Vd}_{\mathrm{ss}}$ : Volume of distribution at steady state; $\mathrm{Cl}_{\mathrm{B}}$ : Total body clearance; MRT: Mean residence time; MAT: Mean absorption time; $\mathrm{C}_{\max }$ : Maximum drug concentration; $\mathrm{T}_{\max }$ : Time to peak plasma drug concentration; F: Bioavailability.

Table 2: Mean \pm SE plasma pharmacokinetic parameters of orbifloxacin in goats $(n=6)$ following intravenous intramuscular administration at a dose rate $2.5 \mathrm{mg} / \mathrm{kg}$ body weight. 
Citation: Ghanshyam D, Avinash, Divyesh K, Madhavi A, Bhavesh C, et al. (2015) Pharmacokinetics of Orbifloxacin in Mehsana Goats after Intravenous and Intramuscular Administration. J Veterinar Sci Technol 6: 237. doi:10.4172/2157-7579.1000237

Page 3 of 4

penetration through biological membranes and was consistent with other species, including horses $4.04 \mathrm{~L} / \mathrm{kg}$ [9] and $1.58 \mathrm{~L} / \mathrm{kg}$ [10], goats $(1.13 \mathrm{~L} / \mathrm{kg} ;[11]$ and $(4.78 \mathrm{~L} / \mathrm{kg} ;[21]$, camels $(1.73 \mathrm{~L} / \mathrm{kg}) ;[12]$, rabbits $(1.71 \mathrm{~L} / \mathrm{kg}) ;[13]$, sheep $(1.31 \mathrm{~L} / \mathrm{kg} ;[15]$ and $3.09 \mathrm{~L} / \mathrm{kg}) ;[16]$, cattle $(0.92 \mathrm{~L} / \mathrm{kg}) ;[14]$, dogs $(1.61 \mathrm{~L} / \mathrm{kg}) ;[8]$, buffaloes $(1.10 \mathrm{~L} / \mathrm{kg}) ;[18]$ and Japanese quail $(1.27 \mathrm{~L} / \mathrm{kg}) ;[17]$.

The calculated half-life of elimination following intravenous administration in this study was $(8.63 \pm 0.130 \mathrm{~h})$, almost same than in sheep $(8.31 \mathrm{~h})$; [16], shorter than in horses $(9.06 \mathrm{~h})$; [9] and, longer than that reported in birds (4.92 h); [19], buffalo (4.98 h); [18], horses (5.08 h); [10], camels $(5.74 \mathrm{~h}) ;[12]$, dogs (7.1 h); [9] and (4.23 h); [8]. In contrast, a much shorter half-life of elimination of orbifloxacin was recorded in Japanese quail (1.71 h); [17].

The systemic clearance of orbifloxacin after intravenous administration in present study $(0.187 \pm 0.002 \mathrm{~L} / \mathrm{kg} / \mathrm{h})$ and similar to that reported in buffalo $(0.16 \mathrm{~L} / \mathrm{kg} / \mathrm{h}) ;[18]$ and sheep $(0.158 \mathrm{~L} / \mathrm{kg} / \mathrm{h})$; [16], but slower than that reported in cattle $(0.24 \mathrm{~L} / \mathrm{kg} / \mathrm{h}) ;[14]$, dogs $(0.31 \mathrm{~L} / \mathrm{kg} / \mathrm{h}) ;[8]$, sheep $(0.32 \mathrm{~L} / \mathrm{kg} / \mathrm{h}) ;[15]$, goats $(0.40 \mathrm{~L} / \mathrm{kg} / \mathrm{h}) ;[11]$ and $1.88 \mathrm{~L} / \mathrm{kg} / \mathrm{h}) ;$ [15], Japanese quail $(0.60 \mathrm{~L} / \mathrm{kg} / \mathrm{h}) ;$ [17] and rabbits $(0.91 \mathrm{~L} / \mathrm{kg} / \mathrm{h}) ;[13]$.

The $\mathrm{C}_{\max }(1.76 \pm 0.010 \mu \mathrm{g} / \mathrm{mL})$ and $\mathrm{T}_{\max }(1.00 \pm 0.00 \mathrm{~h})$ values after intramuscular administration of orbifloxacin in present study were intermediate between those reported in $\operatorname{dogs}(1.15 \mu \mathrm{g} / \mathrm{mL}$ and $1.15 \mathrm{~h}$, respectively; [13], cattle $(1.21 \mu \mathrm{g} / \mathrm{mL}$ and $1.36 \mathrm{~h}$, respectively); [14], sheep $(1.53 \mu \mathrm{g} / \mathrm{mL}$ and $1.25 \mathrm{~h}$, respectively); [15], buffalo (1.6 $\mu \mathrm{g} / \mathrm{mL}$ and $1.3 \mathrm{~h}$, respectively); [18], birds $(1.63 \mu \mathrm{g} / \mathrm{mL}$ and $1.32 \mathrm{~h}$, respectively); [19] and goats $(1.66 \mu \mathrm{g} / \mathrm{mL}$ and $0.87 \mathrm{~h}$, respectively); [11], but much higher to that observed by [15] in goats $(0.36 \mu \mathrm{g} / \mathrm{mL}$ and 0.94 $\mathrm{h}$, respectively). In contrast, lower to that reported in camels $(1.93 \mu \mathrm{g} /$ $\mathrm{mL}$ and $1.52 \mathrm{~h}$, respectively); [12] and similar to that reported in sheep $(1.81 \mu \mathrm{g} / \mathrm{mL}$ and $1.0 \mathrm{~h}$, respectively); [16].

The elimination half-life after intramuscular administration (17.77 $\mathrm{h})$ was much longer than after intravenous administration $(8.63 \mathrm{~h})$ and the slower elimination of orbifloxacin from plasma after intramuscular treatment suggested a 'flip-flop' effect [22]. This would mean that the terminal phase of the plasma concentration-time curve was determined by the absorption rate constant and not by the apparent elimination constant.

The systemic bioavailability of orbifloxacin in sheep after intramuscular administration was extensive $(155.5 \pm 2.487 \%)$ and indicated good absorption from the injection site. It was almost same that have been reported in sheep $150.8 \%$; [16]. Relatively, lower values have been reported in buffalo 91.9\%; [18], goats $92.47 \%$; [15] and $105.01 \%$; [11], camels (97.47\%) [12], dogs $100.1 \%$ [8], cattle $101.4 \%$ [14], rabbits (109.87\%) [13] and sheep 114.63\% [15].

\section{Conclusions}

Orbifloxacin showed favorable pharmacokinetic properties, such as a long half-life and high bioavailability, with no obvious adverse reactions. This drug could therefore be an effective treatment in goats for a number of bacterial infections. However, further studies are needed to establish a multiple dosage regimen and clinical efficacy against susceptible organisms that infect goats.

\section{Conflict of Interest Statement}

None of the authors of this paper has a financial or personal relationship with other people or organizations that could inappropriately influence or bias the content of this paper.

\section{Acknowledgements}

The authors thank to Astron Research Limited, Ahmedabad, India for providing facility to carryout analysis of samples.

\section{References}

1. Ihrke PJ, Papich MG, Demanuelle TC (1999) The use of fluoroquinolones in veterinary dermatology. Veterinary Dermatology 10: 193-204.

2. Matsumoto S, Nakai M, Yoshida M, Katae H (1999) A study of metabolites isolated from urine samples of pigs and calves administered orbifloxacin Journal of Veterinary Pharmacology and Therapeutics 22: 286-289.

3. Hannan PC, Windsor GD, DeJong A, Schmeer N, Stegemann M, et al. (1997) Comparative susceptibilities of various animal-pathogenic Mycoplasmas to fluoroquinolones. Antimicrobial Agents and Chemotherapy 41: 2037-2040.

4. Papich MG, Riviere JE (2001) Fluoroquinolone antimicrobial drugs. In: Adams HR (ed.) Veterinary Pharmacology and Therapeutics (8th edn.) lowa State University Press Ames 898-917.

5. Matsumoto S, Nakai M, Yoshida M, Katae H (1998a) Absorption, distribution and excretion of orbifloxacin in swine and calves. Journal of the Japan Veterinary Medical Association 51: 13-18.

6. Matsumoto S, Takahashi M, Kitadai N, Katae H (1998b) A study of metabolites isolated from urine sample of cats and dogs administered orbifloxacin. The Journal of Veterinary Medical Science 60: 1259-1261.

7. Heinen E (2002) Comparative serum pharmacokinetics of the fluoroquinolones enrofloxacin, difloxacin, marbofloxacin and orbifloxacin in dogs after single oral administration. Journal of Veterinary Pharmacology and Therapeutics 25: 1-5.

8. Gebru E, Lee JS, Chang ZQ, Hwang MH, Cheng H, et al. (2009) Integration of pharmacokinetic and pharmacodynamics indices of orbifloxacin in beagle dogs after a single intravenous and intramuscular administration. Antimicrobial Agents and Chemotherapy 53: 3024-3029

9. Haines GR, Brown MP, Gronwall RR, Merritt KA, Baltzley LK (2001) Pharmacokinetics of orbifloxacin and its concentration in body fluids and in endometrial tissues of mares. Canadian Journal of Veterinary Research 65 181-187.

10. Davis JI, Papich MG, Weingarten A (2006) The pharmacokinetics of orbifloxacin in the horse following oral and intravenous administration. Journal of Veterinary Pharmacology and Therapeutics 29: 191-197.

11. Marin P, Escudero E, Varon EF, Carceles CM (2007) Pharmacokinetics and milk penetration of orbifloxacin after intravenous, subcutaneous and intramuscular administration to lactating goats. Journal of Dairy Science 90: 4219-4225.

12. Goudah A, Abo-El-Sooud K (2008) Pharmacokinetics and milk penetration of orbifloxacin after intravenous and intramuscular injections to dromedary lactating camels (Camelus dromedaries). Journal of Veterinary Pharmacology and Therapeutics 31: 276-280.

13. Marin P, Varon EF, Escudero E, Carceles CM (2008) Pharmacokineticpharmacodynamic integration of orbifloxacin in rabbits after intravenous, subcutaneous and intramuscular administration. Journal of Veterinary Pharmacology and Therapeutics 31: 77-82.

14. Elias G, Lee JS, Hwang MH, Park YS, Cho KH, et al. (2009) Pharmacokinetics and pharmacokinetic/pharmacodynamics integration of orbifloxacin in Korean Hanwoo cattle. Journal of Veterinary Pharmacology and Therapeutics 32: 219 228.

15. Goudah A, Cho HJ, Shin HC, Shim JH, Regmi JL, et al. (2009): Pharmacokinetics and milk distribution characteristics of orbifloxacin following intravenous and intramuscular injection in lactating ewes. Journal of Veterinary Pharmacology and Therapeutics 32: 338-344.

16. Dudhatra GB, Avinash Kumar, Awale MM, Kamani DR, Chauhan BN, et al (2013a) Determination of orbifloxacin in sheep plasma by high performance liquid chromatography with ultraviolet detection after intravenous and intramuscular administration. Journal of Pharmacological and Toxicological Methods 67: 50-53.

17. Hawkins MG, Taylor IT, Byrne BA, Armstrong RD, Tell LA et al. (2011) Pharmacokinetic-pharmacodynamic integration of orbifloxacin in Japanese quail (Coturnix japonica) following oral and intravenous administration. Journal of Veterinary Pharmacology and Therapeutics 34: 350-358

18. Tohamy MA (2011a) Pharmacokinetic interactions of flunixin and orbifloxacin in buffalo calves. Insight Pharmaceutical Sciences 1: 29-33. 
Citation: Ghanshyam D, Avinash, Divyesh K, Madhavi A, Bhavesh C, et al. (2015) Pharmacokinetics of Orbifloxacin in Mehsana Goats after Intravenous and Intramuscular Administration. J Veterinar Sci Technol 6: 237. doi:10.4172/2157-7579.1000237

19. Tohamy MA (2011b) Single oral-dose pharmacokinetics of ibafloxacin and orbifloxacin in chickens. Insight Poultry Research 1: 1-4.

20. Dudhatra GB, Avinash Kumar, Kamani DR, Awale MM, Chauhan BN, et al. (2013b) Comparative Retention Time of Orbifloxacin by High Performance Liquid Chromatography in Goats and Sheep. Invent Impact Pharmacokinetics and Pharmacodynamics 46-50.

21. Abd EIAty AM, Choi JH, Ko MW, Khay S, Goudah A, et al. (2009) Approaches for application of sub and supercritical fluid extraction for quantification of orbifloxacin from plasma and milk: Application to disposition kinetics. Analytica Chimica Acta 631: 108-115.

22. Toutain PL, Melou AB (2004) Plasma terminal half-life. Journal of Veterinary Pharmacology and Therapeutics 27: 427-439.
23. Martinez M, Mcdermott P Walker R (2006) Pharmacology of the fluoroquinolones: a perspective for the use in domestic animals. The Veterinary Journal 172: 10-28.

24. Giles CJ, Magonijle RA, Grimshaw WTR, Tanner AC, Risk JE, et al. (1991) Clinical Pharmacokinetics of parentreal administered danofloxacin in cattle. Journal of Veterinary Pharmacology and Therapeutics 14: 400-410.

25. Gutierrez CB, Rodriguez EF (1993) In Vitro susceptibility of Pasteurella multocida subspecies multocida strains isolated from swine to 42 antimicrobial agents. Zentralbl. Bakteriol. 270: 387-393. 